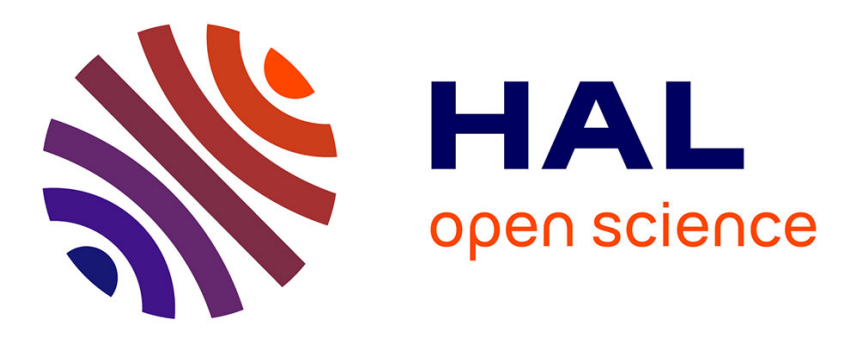

\title{
A Comparative Study of Maize and Miscanthus Regarding Cell-Wall Composition and Stem Anatomy for Conversion into Bioethanol and Polymer Composites
}

M. Brancourt-Hulmel, S. Arnoult, L. Cézard, F El Hage, E. Gineau, J. Girones, Y. Griveau, M.-P. Jacquemont, S. Jaffuel, E. Mignot, et al.

\section{To cite this version:}

M. Brancourt-Hulmel, S. Arnoult, L. Cézard, F El Hage, E. Gineau, et al.. A Comparative Study of Maize and Miscanthus Regarding Cell-Wall Composition and Stem Anatomy for Conversion into Bioethanol and Polymer Composites. BioEnergy Research, In press, 10.1007/s12155-020-10239-z . hal-03517627

\section{HAL Id: hal-03517627 \\ https://hal.science/hal-03517627}

Submitted on 7 Jan 2022

HAL is a multi-disciplinary open access archive for the deposit and dissemination of scientific research documents, whether they are published or not. The documents may come from teaching and research institutions in France or abroad, or from public or private research centers.
L'archive ouverte pluridisciplinaire HAL, est destinée au dépôt et à la diffusion de documents scientifiques de niveau recherche, publiés ou non, émanant des établissements d'enseignement et de recherche français ou étrangers, des laboratoires publics ou privés. 


\title{
A comparative study of maize and miscanthus regarding cell-wall composition and stem anatomy for conversion into bioethanol and polymer composites
}

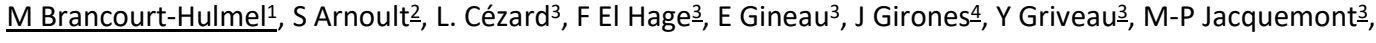

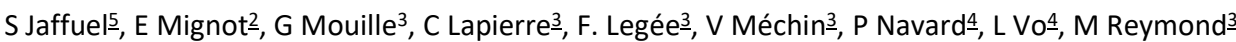 \\ 1 BioEcoAgro Joint Research Unit - INRAE Agrolmpact - Université de Liège - Université de Lille - Université de Picardie Jules \\ Verne, Site d'Estrées-Mons CS 5013680203 Péronne cedex (France) \\ 2 INRAE UE GCIE Picardie, Estrées-Mons 80203 Péronne (France) \\ 3 Institut Jean-Pierre Bourgin, INRAE, AgroParisTech, Université Paris-Saclay, 78000, Versailles, France \\ 4 Mines ParisTech, PSL - Research University, CEMEF - Centre de Mise en Forme des Matériaux, UMR CNRS 7635, CS 10207, \\ Rue Claude Daunesse, 06904 Sophia Antipolis Cedex (France) \\ 5 CIRAD, UMR AGAP, Montpellier, France
}

Corresponding author: Maryse.Hulmel@inrae.fr

\section{ABSTRACT}

Due to an increasing demand for environmentally sustainable products, miscanthus and maize stover represent interesting lignocellulosic resources for conversion into biofuels and biomaterials. The overall purpose was to compare miscanthus and maize regarding cell-wall composition and stem anatomy for conversion into bioethanol and polymer composites using partial least squares regressions. For each of the two crops, six contrasted genotypes were cultivated in complete block design, and harvested. Internodes below the main cob for maize, and on the first aboveground internode for miscanthus, were analyzed for biochemistry and anatomy. Their digestibility was predicted using crop-specific near infrared calibrations, and the mechanical properties were evaluated in stem-based composites.

On average, the internode cross-section of miscanthus anatomy was characterized by a thick rind $(26.2 \%)$ and few but dense pith-bundles $\left(3.5 \mathrm{nb} / \mathrm{mm}^{2}\right)$, while cell-wall constituted $95.2 \%$ of the dry matter with high lignin $(243.2 \mathrm{mg} / \mathrm{g})$ and cellulose concentrations $(439.7 \mathrm{mg} / \mathrm{g})$. Maize internode-anatomy showed large cross-sections $\left(397.5 \mathrm{~mm}^{2}\right)$, pith with the presence of numerous bundles and non-lignified-pith fractions (22.3\% of the section). Its cellwall biochemistry displayed high concentrations of hemicelluloses, galactose, arabinose, xylose and ferulic acid. Cell-wall, lignin and cellulose concentrations were positively correlated with rind-fraction and pith-bundle-density, which explained strong mechanical properties as shown in miscanthus. Hemicelluloses, galactose, arabinose and ferulic acid concentrations were positively correlated with pith fraction and stem cross-section, revealing high digestibility as shown in maize. This underlines interesting traits for further comparative genetic studies, as maize represents a good model for digestibility and miscanthus for composites.

\section{Key-words}

Energy crop, lignocellulosic biomass, biomaterials, polysaccharides, enzymatic hydrolysis, biofuels

\section{Introduction}

Biomass crops represent lignocellulosic stocks for conversion into biofuels and biomaterials [1]. The International Renewable Energy Agency predicted that biomass could account for $60 \%$ of the total final renewable energy use by 2030 (global renewable energy roadmap, REmap 2030). To face such an increasing demand, it is necessary to focus on crops that show high productivity and nutrient-use efficiencies, as well as a favorable balance regarding greenhouse gas emissions. The best way to reduce 
the impact on global food security is to cultivate the crops dedicated to biomass production on marginal lands or to use food crop residues as by-products.

Maize without a cob, known as maize stover, and miscanthus are nonfood stocks. Maize is usually cultivated as a food or feed crop. Maize stover constitutes a by-product of food or biofuel production and may be integrated in the biorefining process in order to increase the value chain $[2,3]$. Miscanthus is a dedicated perennial crop and shows several potential biorefining applications such as biofuel [4] or biomaterials [5].

As for other grasses, the stems of maize and miscanthus are made up of a rind that is composed of a dense outer tissue and a softer pith located in the middle of the stem. At maturity, hollow stems appear but undegraded piths do exist, which increases the density of the stem and contributes to biomass yield [6].

Plant biomass is mostly constituted of the cell-wall (CW). Plant cell-walls contain fibrils of cellulose deeply inserted in a network of structural polysaccharides (hemicelluloses and pectins), lignins, and proteins [7]. The proportions of these CW polymers substantially vary according to the plant species, development stage, organ and cell-type [7]. Cellulose is a polymer composed of glucose only, while hemicelluloses mainly consist of five different sugar monomers either with six carbons (galactose, glucose, mannose) or five carbons (xylose and arabinose). In grass cell-walls, hemicellulosic polysaccharides are mainly composed of arabinoxylans whose arabinose substituents may mainly be acylated by ferulic acid (FA) and, to a lower extent, by $p$-coumaric acid (pCA). Moreover, lignins are highly resistant to degradation and provide compression strength to the walls [8]. During the lignification of grass cell-walls, ferulic units that are ester-linked to arabinoxylans may be oxidatively linked to lignin units, and these ferulate-mediated bridges between lignins and arabinoxylans may substantially affect cell-wall properties [9].

Composites are materials made of at least two different non-miscible components, and are usually produced with thermoset and thermoplastic reinforced with natural, synthetic or inorganic fibers [10]. Due to a greater demand for environmentally sustainable materials, glass fiber is being more and more substituted with plant fibers. The recent development of an optimized small-scale protocol has now enabled the comparison of several miscanthus genotypes [5] or maize genotypes [11]. The role of stem morphology, anatomy, and chemistry on the mechanical properties of composites, such as modulus of elasticity and strength at break, has rarely been documented in the two crops. In maize, the best composite performances were obtained with stems that showed higher concentrations of cell-wall, lignin, $p$-coumaric acid and cellulose in association with lower concentrations of ferulic acid and hemicellulose [11]. In contrast, this has not been studied yet in miscanthus. The enzymatic hydrolysis of CW polysaccharides (referred to as saccharification) provides sugar monomers that can be fermented into bioethanol. In contrast to composites, the role of $\mathrm{CW}$ composition and structure in saccharification efficiency is well documented for maize stover [2, 12]. In miscanthus, genotype saccharification performances have been analyzed regarding the composition $[13,14]$ and the fine structure of its CW polymers [5, 15]. Saccharification efficiency is negatively correlated with lignin while the structural features of arabinoxylan and xyloglucan are found to contribute positively to hydrolysis [15].

The objective of the present study was to compare miscanthus and maize regarding the role of both stem anatomy and chemistry in the mechanical properties of composites, while focusing on three questions. Which biochemical and anatomical variables best discriminate the two crops? What links exist among the anatomical and biochemical variables, both within and between these two groups of variables? Are there differences between crops in which and how variables explain digestibility and mechanical properties of stem-based polymer composites? It can be predicted that both crops would be contrasted in their stem anatomy and biochemistry, which could involve strong common features in their performances as well as differences for polymer composites or ethanol production.

\section{Materials and methods}




\section{Main features}

All plant stems, their histological structure, biochemistry, digestibility or the mechanical properties of the corresponding stem-based composites were analyzed using samples from the same initial plots for both crops. In particular, biochemical analyses were performed on the sieved stem fragments that were used for preparing the composites. For maize, the elongated internode below the main cob was used to perform the experiments as it is the most representative of stem internodes [16]. For miscanthus, the first aboveground internode was used to represent the plant in a simple way as the genotypes differ widely in internode number. The plant material, biological and technical analyses were as follows. For maize, the comparison is based on data that have already been used to document the role of both stem anatomy and chemistry in the mechanical properties of composites [11] while the data has not been published yet for miscanthus. Data are given in supplemental Tables 1, 2, 3 and 4. Plant material

The maize was sown in April 2014 at INRAE Le Moulon (Gif sur Yvette, France) according to a complete block design with 4 blocks. Each plot consisted in four to six randomized rows per genotype, from which ten to twenty plants were harvested. Six maize inbred lines were cultivated: $\mathrm{Cm} 484, \mathrm{~F} 2, \mathrm{~F} 271$, F2 bm3, F66, and F98902. They were selected in order to represent a wide range of cell-wall degradability and lignin content in the cell-wall, based on phenotypic variations observed in maize lineages [16]. Harvests were performed in September at the silage stage for each line ( $30 \%$ of dry matter). All the early-flowering lines except F98902 were harvested on the 1st September 2014 whereas the late-flowering F98902 was harvested on the 22nd September 2014. For more details concerning sample preparation, see Vo et al. [11].

Regarding miscanthus, the trial was planted by hand in spring 2007 at INRAE Estrées-Mons (Péronne, France) according to a complete block design with three blocks, at a rhizome planting density of 2 plants per $\mathrm{m}^{2}$. Each harvested plot consisted of $16 \mathrm{~m}^{2}$ which contained four rows of eight plants and each plot was surrounded by a border row. The miscanthus trial received no nitrogen input and weeds were regularly removed manually. No fertilizer and pesticides were applied. The crop cycle ended at the first frost which occurred on the 28th December 2014. The harvest was performed on a mature eight-year old crop on the 9th and 10th February 2015 when the dry matter content reached $65 \%$ on average. Six contrasted genotypes were studied. Two of the clones were $M$. $x$ giganteus interspecific hybrids: a biomass clone (coded GIB) and an ornamental variety, Floridulus (FLO). Two other clones belonged to the $M$. sinensis species: a biomass tetraploid Goliath variety (GOL) and a diploid ornamental Malepartus variety (MAL). The two remaining ones belonged to the $M$. sacharriflorus species: a biomass tetraploid (H5) and an ornamental diploid (SAC). The GIB, GOL and H5 biomass clones were provided by ADAS (GB), the Nordic biomass company (DK) and the Danish institute of agricultural science of Aarhus, respectively. The three remaining ones were acquired from the Chombard gardening nursery (France). They were chosen to offer wide phenotypic variability [17].

For both trials, field soil types were deep loam. Meteorological data were downloaded from the CLIMATIC database (INRAE AGROCLIM, 2020). In both trials, monthly mean temperatures and precipitation were very similar: the mean temperature was $0.5^{\circ} \mathrm{C}$ higher in Le Moulon while the monthly mean precipitation was $6 \mathrm{~mm}$ higher in Mons. In both cases, summers were rainy and March, April and September were very dry (Figure 1). Although the two crops were harvested at two different dry matter content levels, these harvests were representative of farming practices and corresponded to the biomass currently commercialized for both crops. Aboveground biomass yields are given in supplemental Table 5 for both crops.

\section{Preparation of plant samples}

Fifty grams of miscanthus or maize harvested stems were dried and ground after being mildly dried in a Hellweg M50 granulator equipped with a $2.5 \mathrm{~mm}$ sieve. The size of the fragments was further reduced by means of a coffee mill (Carrefour home) operated for 1 minute in sequences of 10 seconds. In order to ensure homogeneous fragment size, stem fragments were subsequently sieved in a Retsch AS200 Digit shaker.

\section{Biochemical variables}


Before exhaustive water removing, the miscanthus samples were submitted to water and then ethanol extraction in a soxhlet apparatus. The recovered extractive-free samples, which correspond to cellwalls, were dried at $50^{\circ} \mathrm{C}$ before their composition was analyzed. The Klason lignin (KL) content was measured at approximately $300 \mathrm{mg}$ (weighed to the nearest $0.1 \mathrm{mg}$ ) and according to Méchin et al. [18]. The monosaccharide composition of miscanthus cell wall components was analyzed as follows: $10 \mathrm{mg}$ dry weight of ground samples $(<100 \mu \mathrm{m})$ were washed twice in $80^{\circ} \mathrm{C}$ water, twice in four volumes of absolute ethanol at $80^{\circ} \mathrm{C}$ for $15 \mathrm{~min}$. They were rinsed twice in four volumes of acetone at room temperature for $10 \mathrm{~min}$ and were left to dry at room temperature under a fume hood overnight. After hydrolysis, $10 \mathrm{mg}$ of this cell wall residue were kept in $2.5 \mathrm{M}$ trifluoroacetic acid at $100{ }^{\circ} \mathrm{C}$ for 1.5 hour. To determine the cellulose content, the residual pellet obtained after the trifluoroacetic acid hydrolysis was rinsed twice with ten volumes of water and was hydrolyzed with $\mathrm{H}_{2} \mathrm{SO}_{4}$ as described by Updegraff [19]. Then, the released monosaccharides were diluted 500 times at least and quantified using an HPAEC-PAD chromatography as described by Harholt et al. [20]. Ester-linked $p$-coumaric acid (pCA) and ferulic acid (FA) units were measured by mild alkaline hydrolysis, followed by a solid-phase extraction and then HPLC analyses according to Ho-Yue-Kuang et al. [21]. It is important to note that all these biochemical variables are stable across the years. A maize three-year study of the $\mathrm{F} 271 \times$ Cm484 RIL progeny indeed revealed no interaction between the genotype and the year [22]. About miscanthus, KL, pCA and FA were measured for two consecutive years of testing and sampling (2014, 2015) and the corresponding year effect was not significant (supplemental Table 6).

\section{Anatomical variables}

Five anatomical variables were observed in both crops. The first one consisted in the evaluation of the area of the stem cross-section of the internode observed (coded StArea). The rind fraction was determined for each cross-section (Rind, in \%), and corresponds to the external area that encompasses the epidermis. This fraction surrounds the pith fraction that was also determined (Pith, in \%). The bundle number in pith represents the bundle number present in the pith (NbBund) while the bundle intensity corresponds to a density of bundles in the pith (InBund). For each sampled internode of both crops, a 1-cm-long segment was sampled and fine-cut into cross-sections that were thereafter Fasgastained. Prepared glass slides were then scanned and converted into high-resolution images (Figure 2). In maize, the whole protocol was described by Legland et al. [23]. In miscanthus, stem anatomy was described using a $1 \mathrm{~cm}$ long segment of the first internode of each genotype according to the protocol detailed in Luquet et al. [24].

\section{Digestibility of the stems}

For both crops, the acid pretreatment of the dry matter followed by a cellulolysis (Onozuka cellulase) for in vitro dry matter degradability (coded Digest) were predicted with crop specific NIRS calibrations. In maize, the NIRs equations were published in Virlouvet et al. [22] and the same procedure was applied in miscanthus using a core of 76 samples representing a wider database of samples harvested during winter.

\section{Stem-based composite preparation}

The preparation of composites based on plant stem fragments and the methods for measuring their mechanical properties were described in detail in Girones et al. [5] for miscanthus and Vo et al. [11] for maize. The main features regarding miscanthus and maize are briefly underlined here, stressing the differences between the treatments of these two crops.

Maize-based composites were prepared using a polyethylene matrix (low-density polyethylene LDPE 1965T, SABIC Europe) and a coupling agent, which corresponded to high-density polyethylene with a high content of maleic anhydride (MA-g-PE), Orevac ${ }^{\circledR} 18507$ (Arkema, France). Miscanthus-based composites were prepared using polypropylene (Addilene from Arkema). A maleic anhydride grafted polypropylene (MA-g-PP) supplied by Eastman (code name G-3015) was used as coupling agent.

Prior to compounding, the fractions to be used in the composites were selected from the ground samples using a $100 \mu \mathrm{m}$ sieve for miscanthus and $200 \mu \mathrm{m}$ and $300 \mu \mathrm{m}$ sieves for maize. The sieved miscanthus and maize fragments were dried overnight in an air-circulating oven operating at $60^{\circ} \mathrm{C}$. Composite blends comprising $30 \%(\mathrm{w} / \mathrm{w})$ stem fragments, polymer and coupling agent (proportion of $5 \mathrm{wt} \%$ on a dry stem fragment basis) were compounded in a Haake-rheomix intensive kinetic mixer, 
and temperatures set at $180^{\circ} \mathrm{C}$ for miscanthus and $150^{\circ} \mathrm{C}$ for maize. After they were compounded, the composites were granulated in a blade mill and kept in an oven at $80^{\circ} \mathrm{C}$ before being injection-molded in a Haake Minijet-II (Thermo Scientific) using a steel mold complying with ISO-527-2-1BA specifications, imposing $150^{\circ} \mathrm{C}$ for the barrel and $40^{\circ} \mathrm{C}$ for the mold for maize and $200^{\circ} \mathrm{C}$ for the barrel and $70^{\circ} \mathrm{C}$ for the mold for miscanthus.

Test bars were allowed to rest in a conditioned-room at $25^{\circ} \mathrm{C}$ and $50 \%$ humidity for at least three days before mechanical testing. Tensile tests were carried out in a Zwick Z2.5 tensile testing machine with a force cell of $2.5 \mathrm{kN}$, operating at $0.02 \mathrm{~mm} / \mathrm{s}(1.2 \mathrm{~mm} / \mathrm{min})$ with a $55 \mathrm{~mm}$ gap between grips and $2 \mathrm{kN}$ pre-tension (ASTM D618 -Procedure A). Charpy V-notch impact tests were conducted on a pendulum Ceast 9050 with a 1-J swinging arm. A 2-mm indent was made onto impact bars using a single tooth Ceast NotchVIS manual notching machine. These tests follow ASTM 638 and 790 standards. Each reported result is the mean value of ten tests.

Reasons for preparation differences between maize and miscanthus._Unpublished results obtained in the laboratories of Mines ParisTech-CEMEF showed that the thermal resistance of maize fragments is lower than that of miscanthus fragments. While composites of miscanthus could be prepared in polypropylene, this was not advisable for maize due to a suspicion of degradation, and a lower processing temperature polymer, polyethylene, was chosen. However, it was shown that the order and relative magnitude of the mechanical properties of composites of different miscanthus genotypes was the same in polyethylene and polypropylene, which highlights the relevance of all the mechanical results of maize and miscanthus composites used for this study. In addition, the values of miscanthus were corrected by the sieve effect calculated in a previous study. In this study, the mean effect was 1.6 MPa for tensile strength (TS) and $0.0773 \mathrm{GPa}$ for Young's modulus (YM) between $100 \mu \mathrm{m}$ and 200 $\mu \mathrm{m}$ sieve. The correction factor was -3.2 MPa for TS and -0.1546 GPa for YM and was applied to all miscanthus genotypes as no interaction was observed between the sieve size and the genotype for both variables.

\section{Statistical analyses}

All variables were initially analyzed according to an analysis of variance using the aov function of the Agricolae R package (version 3.5.1). For anatomical and biochemical variables, the model included the species and the genotype effects as well as the block effect in interaction with the species. The SNK.test function was used for mean multiple comparison with a Student-Newman-Keuls test. For digestibility and mechanical properties, the repetitions were not included as a factor as they corresponded to technical repetitions.

An exploratory data analysis consisted in a Partial Least Squares Discriminant Analysis (PLS-DA) using the plsDA function of the DiscriMiner $\mathrm{R}$ package to perform a standard partial least squares regression to classify samples. It was used in this study to provide good insight into the causes of discrimination between the two levels (maize and miscanthus) of the $Y$ crop qualitative variable by identifying, among the $X$ matrix of quantitative variables related to the stem anatomy and biochemistry, those that contribute to such discrimination. A PLS analysis of a second type was carried out using the plsreg2 function of the plsdepot package. This PLS, usually coded PLS2 [25], performs a partial least squares regression in the multivariable case, i.e. for more than one response variable [26]. The stem anatomy variables were used as a $Y$ matrix of response variables while the stem biochemistry variables were used as an X matrix of predictors. Finally, a third type of PLS analyses focused on partial least squares regressions for the univariable case, i.e. one response variable [26], using the plsreg1 function of the plsdepot package. In this PLS, usually coded PLS1 [25], digestibility was used as a single Y quantitative response variable while stem anatomy and biochemistry variables were used as an $\mathrm{X}$ matrix of predictors. Additional PLS1 were also performed where mechanical properties (tensile strength or Young's modulus) were explained using the same previous $\mathrm{X}$ matrix of predictors.

\section{Results}

Partial Least Squares Discriminant Analysis PLS-DA distinguished the two crops according to distinct stem anatomy and biochemistry variables

A PLS DA was performed to discriminate maize and miscanthus using the crop $Y$ qualitative variable and all quantitative $X$ variables related to the anatomy and the biochemistry of their stems (Tables 1 , 
2 and 3). Figure 3 displays the PLS correlation-loading plot for these components. It shows the correlation between the quantitative variables, biochemical or anatomical, and the PLS components, and how the crops (red text) correlate with the variables. Variables further away from the origin display a greater influence on the PLS components. On this plot, the two crops were clearly separated with variables contributing to the first component, as these variables form clear clusters and correlate with their respective crop category. $90 \%$ of the variance in the $Y$ qualitative data was indeed explained by this first component, which gave an excellent summary of the three tables (tables 1, 2 and 3). On the left-hand side, miscanthus was well distinguished by two anatomical variables, the external fraction of the stem cross-section, namely rind fraction (Rind), and the bundle density in the pith (InBund). Rind miscanthus reached $26.2 \%$ on average and $\ln B$ und $3.5 \mathrm{nb} / \mathrm{mm}^{2}$ in contrast with maize $(13.1 \%$ and 0.2 $\mathrm{nb} / \mathrm{mm}^{2}$, respectively, table 2). Moreover, three biochemical variables of miscanthus stems stood out: the cell-wall, cellulose, and lignin contents (CW, Cell and KL respectively). For these variables, miscanthus reached $95.2 \% \mathrm{DM}, 439.7 \mathrm{mg} / \mathrm{g} \mathrm{CW}, 243.2 \mathrm{mg} / \mathrm{g} \mathrm{CW}$ on average while maize recorded $61.3,399.8$ and 166, respectively (Tables 1 and 2). Maize was positioned on the right-hand side where the cross-section area of the stem (StArea), the pith corresponding to the internal fraction of the stem (Pith) and the non-lignified fraction of the pith (NLpith) contributed to the main anatomical variables. On average, these variables rose to $397.5 \mathrm{~mm}^{2}, 81.9 \%$ and $22.3 \%$ of pith for maize while miscanthus indicated $57.4 \mathrm{~mm}^{2}, 73.8 \%$ and $10.5 \%$, respectively (Table 2 ). Regarding the biochemical variables, the contributions of the contents of galactose (Gal), ferulic acid (FA), and hemicelluloses (Hcel), and arabinose (Ara) to a lesser extent were the most noticeable. In contrast, the $p$-coumaric acid content (pCA) and the bundle number in pith (NbBund) were found to only contribute to the second component and therefore seemed to be independent from the distinction between the two crops. Indeed, the species effect was not significant for pCA (Table 1). Albeit NbBund was significant, the species means were not highly different (124.9 for maize and 104.8 for miscanthus) and the groups of means overlapped with the two species groups (Table 2 ).

PLS2 highlighted correlations within the sets of biochemical and anatomical variables, as well as between the two groups of variables

Another PLS2 (PLS2 type) was performed using the $Y$ stem anatomy variables as response variables and the $X$ stem biochemistry variables as predictors. It highlighted correlations within the sets of biochemical and anatomical variables, as well as between the two groups of variables. Table 4 shows that the first component $\mathrm{t} 1$ accounted for a significant proportion of the $\mathrm{X}$ matrix variance (82\%) while two components were needed to explain the $Y$ matrix variance ( $47 \%$ in $\mathrm{t} 1$ and $15 \%$ in $\mathrm{t} 2$ ). Lastly, the first two components of this PLS2 accounted for up to $94 \%$ of variances in the X biochemical data and $62 \%$ of the variances in the $Y$ anatomical data.

The loading plot in Figure 4 made it possible to visualize the correlation structure of the $Y$ anatomical variables (text in red) and $X$ biochemical variables (text in green) in the first two components. Two groups of variables were strongly correlated to the first component. Among the $Y$ anatomical variables, negative loadings were observed on the left-hand side for the rind fraction (Rind), and the pith bundle density (InBund). On the right-hand side, positive loadings were related to the area of the stem section (StArea), the pith (Pith), and the non-lignified fraction of the pith (NLpith) to a lesser extent. Concerning the $X$ biochemical variables, negative loadings were noticeable for the cell-wall, cellulose, and lignin contents (CW, Cell and KL, respectively) and the positive contributions for the contents of galactose (Gal), hemicelluloses (Hcel), xylose (Xyl), ferulic acid (FA), and arabinose (Ara). In summary, a trend was observed along this first component in which cell-wall, lignin and cellulose concentrations were positively correlated with rind fraction and pith bundle density while hemicelluloses, galactose, xylose, ferulic acid and arabinose concentrations were mainly positively correlated with the pith fraction and the area of the stem cross-section. Regarding the plot of observations (i.e. genotypes) in the two first principal components, miscanthus genotypes (red text in Figure 5) showed the highest values for the first group of biochemical and anatomical variables highlighted in the first component (those with negative loadings in Figure 4). In contrast, maize genotypes, and particularly F2 bm3 and F66 (blue text in Figure 5), were those displaying the highest values for the second group of variables, which corresponded to the positive loadings. Regarding biochemical variables, miscanthus reached 243.2 
$\mathrm{mg} / \mathrm{g} \mathrm{CW}$ for KL and $439.7 \mathrm{mg} / \mathrm{g} \mathrm{CW}$ for HCell while maize obtained 166.1 and 399.8, respectively. In contrast, maize showed higher values for Hcel, Xyl and Gal (296.7, 207.2 and $9.0 \mathrm{mg} / \mathrm{g} \mathrm{CW}$, respectively) than miscanthus $(170.1,146.0,2.3$, respectively, Table 1$)$. About the anatomical variables, maize obtained $397.5 \mathrm{~mm}^{2}, 81.9 \%, 22.3 \%$ for StArea, pith and NLpith, respectively, whereas miscanthus recorded 57.4, 73.8 and 10.5 , respectively. Conversely, miscanthus reached $26.2 \%$ and 3.5 $\mathrm{nb} / \mathrm{mm}^{2}$ for Rind and InBund, respectively, while maize showed 13.1 and 0.2 , respectively (Table 3 ). In the second component, a single maize genotype was noticeable (F98902) as it showed the highest vascular bundle number in its pith (NbBund) and its high p-coumaric acid content (pCA), 173.5 and $28.3 \mathrm{mg} / \mathrm{g} \mathrm{CW}$ (Tables 2 and 1, respectively). In contrast, another maize genotype (F2bm3) and two miscanthus genotypes (Malepartus and Goliath) showed the lowest concentrations of $p$-coumaric acid (lower or equal to $15.7 \mathrm{mg} / \mathrm{g} \mathrm{CW}$, Table 1) while their bundle number in pith was rather low (less than or equal to 104.5, Table 2). Briefly, the first component distinguished the species for a great number of variables while the second component showed variability within the species with an overlap of the two species for pCA.

PLS1 showed distinct anatomical and biochemical variables that account for stem digestibility and mechanical properties, highlighted in maize for the former and in miscanthus for the latter

PLS1 regression models were separately built for each conversion capability, i.e. conversion into biofuels or conversion into polymer composites. The biofuel conversion capability was assessed based on digestibility (Digest). On average, the digestibility of maize biomass reached $64.5 \%$ while miscanthus displayed only $8.2 \%$ (Table 3). The capability to reinforce composites was assessed using two mechanical properties, Young's modulus (YM) and tensile strength (TS): Maize YM and TS averaged 0.7 GPa and 9.0 MPa, respectively, whereas those of miscanthus reached $3.1 \mathrm{GPa}$ and $36.6 \mathrm{MPa}$, respectively (Table 3). As these two mechanical properties were tightly correlated $(r=0.99,0.80$ and 0.96 for both maize and miscanthus, respectively), the results focused on the presentation of tensile strength. This variable was negatively correlated to digestibility ( $r=-0.99,-0.78$ and -0.55 , for both crops together, maize and miscanthus, respectively).

The results of an initial PLS1 using digestibility as a Y response variable were displayed in Figure 6. 94\% of the variance was explained by the first component and $4 \%$ by the second when the data of both crops were considered (Figure 6a). Given the correlation structure shown in this figure, a general trend can be observed in the first component: high digestibility (blue text) was mostly accounted for by the contents of hemicelluloses, galactose, arabinose and ferulic acid that were themselves mainly positively correlated with the pith fraction and stem cross-section. In contrast, low digestibility was accounted for by cell-wall, lignin and cellulose concentrations, themselves positively correlated with the rind fraction and pith bundle density. The second component was omitted as it poorly contributed to the variance. Focusing on Figure $6 \mathrm{~b}$ where the PLS1 only used the maize data, the first component accounted for a lower part of the variance than for both crops (86 \%). In the first component, high digestibility was still mostly explained by the ferulic acid, galactose and arabinose contents as well as pith fraction while the variables that were previously underlined in Figure 6a, still showed a positive contribution, but to a lesser extent. Conversely, low digestibility was still clearly explained by the five variables highlighted when gathering the two crops. Interestingly, this maize PLS1 pointed out the contribution of the $p$-coumaric acid content to such low digestibility. The second component gathered $14 \%$ of the variance and showed a contrast between the stem area, pith bundle density, and hemicelluloses on the one hand, and lignin, $p$-coumaric acid contents on the other. Regarding the miscanthus PLS1 (Figure 6c), a few variables still explained digestibility: the hemicelluloses, ferulic acid, xylose and arabinose contents explained high digestibility while lignin content contributed to low digestibility. When comparing the two crops, differences stood out in the stem area and the galactose concentration that were shown to contribute to poor digestibility in miscanthus and rather good digestibility in maize.

Regarding the capability of these crops to reinforce composites, a final PLS1 was carried out using tensile strength as a $\mathrm{Y}$ response variable (Figure 7). As for digestibility, the first component gathered a very high proportion of the variance $(92 \%)$ when both crops were considered (Figure 7a). Given the correlation structure shown in this figure, a general trend can easily be observed in the first 
component: high tensile strength (blue text) was clearly explained by all the variables that contributed to poor digestibility while a poor mechanical property was clearly explained by the variables involved in high digestibility. This trend was also observed within each crop, but to a lesser extent in miscanthus than in maize (in figures $6 c$ and $6 \mathrm{~b}$, respectively).

\section{Discussion}

The comparison of the two crops showed that the stem-anatomy of miscanthus was characterized by a thick rind and few but dense pith-bundles, while its stem biochemistry displayed high cell-wall, lignin and cellulose concentrations. In contrast, maize stem-anatomy showed large stem cross-sections, pith and non-lignified-pith fractions, and in the case of biochemical variables, high concentrations of hemicelluloses, galactose, arabinose, xylose and ferulic acid. Cell-wall, lignin and cellulose concentrations were positively correlated with rind-fraction and pith-bundle-density, as shown in miscanthus, while hemicellulose, galactose, arabinose and ferulic acid concentrations were positively correlated with pith fraction and stem cross-section, as shown in maize. Finally, the former set of between-group variables explained the mechanical properties of composites, while the latter explained digestibility. However, some of these variables played a greater role than others as they appeared in both crops, and even in each crop, while other variables were specific to the crops. The greater role of some variables regarding digestibility and mechanical properties is initially discussed below. Then, the discussion focuses on the specificity of each crop regarding stem anatomy and biochemistry. The interest of such a comparison between the two crops is finally discussed.

\section{Some variables played a greater role for both crops and end-uses}

Strong features were revealed by these analyses. Firstly, a good digestibility, and conversely poor mechanical property, was observed for both crops when they displayed large pith fractions and a high concentration of ferulic acid. Secondly, good mechanical properties, along with poor digestibility, were found to be best explained by a high lignin concentration in both crops.

Vo et al. [11] previously found that maize stems with higher concentrations of cell-wall, lignin, $p$ coumaric acid and cellulose in conjunction with lower concentrations of ferulic acid and hemicelluloses yielded better composite performances. Regarding cell-wall digestibility, Jung et al. [27] found that maize pith was more degradable than the rind. Méchin et al. [28] reported that the stem digestibility of maize was negatively correlated with their Klason lignin content while the presence of ferulate was shown to impede the degradation of plant tissue [29]. In miscanthus, Belmokhtar et al. [14] found that the more digestible genotypes contained higher amounts of hemicellulosic carbohydrates and lower amounts of cellulose and lignin. Van der Weijde et al. [30] reported that the most important traits that contributed favorably to the saccharification efficiency of miscanthus were a high content of ferulic acid, a high ratio of $p$-coumaric acid to lignin and a low lignin content.

This underlines the role of lignin content for both end-uses. Lignin promotes the high mechanical properties of stem-based composites in both crops due to its high thermal resistance and its role as a strong bonding agent in cell walls while its resistance to degradation also compromises the digestibility of the stem in both crops.

\section{Each crop displayed specific features regarding stem anatomy and biochemistry}

Besides these common features, the analyses also shed light on additional variables that were specific to each crop. In maize, good digestibility, and conversely poor mechanical properties, were favored by the stem area together with the arabinose content while the hemicelluloses content was specific to miscanthus. Moreover, good mechanical properties, along with bad digestibility, was explained by high cell-wall and cellulose contents in maize. In miscanthus, the area of stem-section appeared to positively contribute to the mechanical properties. This was due to the inversion of the correlation between the area of the cross-stem section and the rind fraction between both crops. This correlation tended to be significantly positive in miscanthus $(0.23)$ while it was significantly negative in maize (0.34).

Regarding stem digestibility, El Hage et al. [16] used the same in vitro dry matter degradability test (IVDMD) as in the present study and observed a negative correlation of the cellulose content with stem digestibility and no significant correlation with the stem area in maize. When applying a different test with mild dilute acid pretreatments, Torres et al. [31] reported opposite results concerning stem 
cellulose content. Concerning mechanical properties, Vo et al. [11] showed the main importance of cellulose content in the relation between the composition and the mechanical properties of maize. It can be noted that these crop specificities were probably accentuated by the time of the harvest that was carried out at two distinct dry matter contents for the two crops. However, Le Ngoc Huyen et al. [32] found that delaying harvest from autumn to winter was mainly related to increased amounts of cell-wall and ester-linked phenolic acids in $M . x$ giganteus, which were not highlighted among the specific traits here. Regarding arabinose content, the difference between the two crops may also have been overestimated as its levels markedly decline in the cell-walls of grasses during plant maturity [2]. Finally, some plant stem anatomy features may be accentuated by the observation of the basal internode in miscanthus, as Kaack et al. [33] showed that the respective areas of the outer rind and pith significantly decreased from the second to the sixth internodes. Nevertheless, these traits did not appear among the specific traits in miscanthus.

This is evidence of the specificity of each crop regarding the anatomical and biochemical traits involved in the digestibility of their stem or in mechanical properties of stem-based polymer composites, despite their harvests at two distinct dry matter levels.

\section{Maize appeared as a model for stem digestibility, and miscanthus for mechanical properties}

The present study revealed strong features involved in stem digestibility or in the mechanical properties of stem-based polymer composites that were common to both species, as well as traits specific to each crop. It was clearly noticeable that maize yielded the best results concerning the digestibility of the stem while miscanthus was better fitted for the production of stem-based polymer composites. Although the harvest of miscanthus in the study was in winter and not in autumn as for maize, a comparable result with an autumn harvest can be predicted as Le Ngoc Huyen et al. [32] showed that the addition of an enzyme cocktail resulted in similar enzyme digestibilities at autumn and winter harvest dates. This suggested that maize could be a central plant model for miscanthus to optimize the cell-wall for improved saccharification to overcome biomass recalcitrance. In their study for defining model plants for lignocellulosic ethanol production, Meineke et al. [34] compared Brachypodium distachyon, wheat, maize, and Miscanthus $x$ giganteus to test whether relative phylogenetic proximity would be sufficient to qualify Brachypodium distachyon as a model plant not only for cell wall composition but also for the process leading to bioethanol production. They correlated phylogenetic proximity with the process of biomass fermentation and observed that a relatively strong correlation between similarities in lignocellulosic ethanol production and phylogenetic relation was only obtained for the stem and leaf biomasses of the two tested C4 grasses. Jonkers [35] also reported that maize became a central model organism for plant research due to its economics importance, which favored research on maize. As illustrated here, it may be relevant to adjust the choice of a model plant not only on the basis of the importance of the available knowledge and phylogenetic proximity but also according to the end-uses for which it is well fitted.

This underlines the importance of both crops in the progress of crop research. Maize can be a model for the miscanthus orphan crop to progress in terms of stem digestibility while miscanthus appears to be a good model for the improvement of mechanical properties.

\section{Conclusion}

This study compared maize and miscanthus regarding cell-wall composition and stem anatomy for conversion into bioethanol and polymer composites. Maize stem-anatomy showed large stem cross-sections, pith and non-lignified-pith fractions, while its biochemical composition revealed high concentrations of hemicelluloses, galactose, arabinose, xylose and ferulic acid. In contrast, the stemanatomy of miscanthus displayed a thick rind and few but dense pith-bundles, and regarding the stem biochemistry, it was characterized by high cell-wall, lignin and cellulose concentrations. As shown in miscanthus, cell-wall, lignin and cellulose concentrations were positively correlated with rind-fraction and pith-bundle-density. In contrast, hemicellulose, galactose, arabinose and ferulic acid concentrations were positively correlated with pith fraction and stem cross-section, as shown in maize. Finally, the former set of between-group variables explained the mechanical properties of composites, while the latter accounted for digestibility. Nevertheless, some of these variables were specific to the 
crops whereas other variables played a greater role than others as they appeared in both crops, and even in each crop. This highlights interesting traits for further comparative genetic studies.

\section{Acknowledgements}

This work has benefited from the support of the programme Investments for the Future (grant ANR-11-BTBR-0006-BFF) managed by the French National Research Agency. The IJPB benefited from the support of IJPB's Plant Observatory technological platforms as well as the support of the LabEx Saclay Plant Sciences-SPS (ANR-10-LABX-0040-SPS). The authors thank the staff of the INRA experimental unit of Estrées-Mons, GCIE Picardie, and in particular, Marie-Chantal Mansard, Marie Heumez-Lévêque, and the students who participated in this work. The authors thank Rebecca James who edited the English text. 


\section{References}

1. Himmel ME, Ding S-Y, Johnson DK, et al (2007) Biomass recalcitrance: Engineering plants and enzymes for biofuels production. Science 315:804-807.

https://doi.org/10.1126/science.1137016

2. Vermerris W, Saballos A, Ejeta G, et al (2007) Molecular breeding to enhance ethanol production from corn and sorghum stover. Crop Sci 47:S142-S153. https://doi.org/10.2135/cropsci2007.04.0013IPBS

3. Gomez LD, Vanholme R, Bird S, et al (2014) Side by Side Comparison of Chemical Compounds Generated by Aqueous Pretreatments of Maize Stover, Miscanthus and Sugarcane Bagasse. BioEnergy Res 7:1466-1480. https://doi.org/10.1007/s12155-014-9480-2

4. Christian DG, Riche AB, Yates NE (2008) Growth, yield and mineral content of Miscanthus $x$ giganteus grown as a biofuel for 14 successive harvests. Ind Crops Prod 28:320-327. https://doi.org/10.1016/j.indcrop.2008.02.009

5. Girones J, Vo L, Arnoult S, et al (2016) Miscanthus stem fragment - Reinforced polypropylene composites: Development of an optimized preparation procedure at small scale and its validation for differentiating genotypes. Polym Test 55:166-172. https://doi.org/10.1016/j.polymertesting.2016.08.023

6. Carpita NC, McCann MC (2008) Maize and sorghum: genetic resources for bioenergy grasses. Trends Plant Sci 415-420. https://doi.org/10.1016/j.tplants.2008.06.002

7. Hatfield RD, Rancour DM, Marita JM (2017) Grass Cell Walls: A Story of Cross-Linking. Front Plant Sci 7:. https://doi.org/10.3389/fpls.2016.02056

8. Kumar M, Campbell L, Turner S (2016) Secondary cell walls: biosynthesis and manipulation. J Exp Bot 67:515-531. https://doi.org/10.1093/jxb/erv533

9. Ralph J, Lapierre C, Boerjan W (2019) Lignin structure and its engineering. Curr Opin Biotechnol 56:240-249. https://doi.org/10.1016/j.copbio.2019.02.019

10. Gallos A, Paes G, Allais F, Beaugrand J (2017) Lignocellulosic fibers: a critical review of the extrusion process for enhancement of the properties of natural fiber composites. RSC Adv 7:34638-34654. https://doi.org/10.1039/c7ra05240e

11. Vo LTT, Girones J, Jacquemot M-P, et al (2020) Correlations between genotype biochemical characteristics and mechanical properties of maize stem - polyethylene composites. Ind Crops Prod 143:. https://doi.org/10.1016/j.indcrop.2019.111925

12. Lorenz AJ, Anex RP, Isci A, et al (2009) Forage quality and composition measurements as predictors of ethanol yield from maize (Zea mays L.) stover. Biotechnol Biofuels 2:. https://doi.org/10.1186/1754-6834-2-5

13. Zhao H, Li Q, He J, et al (2014) Genotypic variation of cell wall composition and its conversion efficiency in Miscanthus sinensis, a potential biomass feedstock crop in China. Glob Change Biol BioEnergy 6:768-776. https://doi.org/10.1111/gcbb.12115

14. Belmokhtar N, Arnoult S, Chabbert B, et al (2017) Saccharification Performances of Miscanthus at the Pilot and Miniaturized Assay Scales: Genotype and Year Variabilities According to the Biomass Composition. Front Plant Sci 8:. https://doi.org/10.3389/fpls.2017.00740 
15. De Souza AP, Kamei CLA, Torres AF, et al (2015) How cell wall complexity influences saccharification efficiency in Miscanthus sinensis. J Exp Bot 66:4351-4365.

https://doi.org/10.1093/jxb/erv183

16. El Hage F, Legland D, Borrega N, et al (2018) Tissue Lignification, Cell Wall p-Coumaroylation and Degradability of Maize Stems Depend on Water Status. J Agric Food Chem 66:4800-4808. https://doi.org/10.1021/acs.jafc.7b05755

17. Zub HW, Arnoult S, Brancourt-Hulmel M (2011) Key traits for biomass production identified in different Miscanthus species at two harvest dates. Biomass BioEnergy 35:637-651. https://doi.org/10.1016/j.biombioe.2010.10.020

18. Mechin V, Laluc A, Legee F, et al (2014) Impact of the Brown-Midrib bm5 Mutation on Maize Lignins. J Agric Food Chem 62:5102-5107. https://doi.org/10.1021/jf5019998

19. Updegraff $D$ (1969) Semimicro determination of cellulose in biological materials. Anal Biochem 32:420+. https://doi.org/10.1016/S0003-2697(69)80009-6

20. Harholt J, Jensen J, Sorensen S, et al (2006) Arabinan deficient 1 is a putative arabinosyltransferase involved in biosynthesis of Pectic Arabinan in Arabidopsis. Plant Physiol 140:49-58. https://doi.org/10.1104/pp.105.072744

21. Ho-Yue-Kuang S, Alvarado C, Antelme S, et al (2016) Mutation in Brachypodium caffeic acid Omethyltransferase 6 alters stem and grain lignins and improves straw saccharification without deteriorating grain quality. J Exp Bot 67:227-237. https://doi.org/10.1093/jxb/erv446

22. Virlouvet L, El Hage F, Griveau Y, et al (2019) Water Deficit-Responsive QTLs for Cell Wall Degradability and Composition in Maize at Silage Stage. Front Plant Sci 10: https://doi.org/10.3389/fpls.2019.00488

23. Legland D, El-Hage F, Mechin V, Reymond M (2017) Histological quantification of maize stem sections from FASGA-stained images. Plant Methods 13:. https://doi.org/10.1186/s13007-017$0225-z$

24. Luquet D, Perrier L, Clement-Vidal A, et al (2019) Genotypic covariations of traits underlying sorghum stem biomass production and quality and their regulations by water availability: Insight from studies at organ and tissue levels. Glob Change Biol BioEnergy 11:444-462. https://doi.org/10.1111/gcbb.12571

25. Tenhenhaus M (1999) L'approche PLS. Rev. Stat. Appliquée 5-40

26. Tenhenhaus M, Gauchi J-P, Ménardo C (1995) Régression PLS et applications. Rev. Stat. Appliquée 7-63

27. Jung $H$, Morrison T, Buxton D (1998) Degradability of cell-wall polysaccharides in maize internodes during stalk development. Crop Sci 38:1047-1051. https://doi.org/10.2135/cropsci1998.0011183X003800040027x

28. Mechin V, Argillier O, Menanteau V, et al (2000) Relationship of cell wall composition to in vitro cell wall digestibility of maize inbred line stems. J Sci Food Agric 80:574-580. https://doi.org/10.1002/(SICI)1097-0010(200004)80:5<574::AID-JSFA575>3.0.CO;2-R 
29. Grabber J, Ralph J, Hatfield R (1998) Ferulate cross-links limit the enzymatic degradation of synthetically lignified primary walls of maize. J Agric Food Chem 46:2609-2614.

https://doi.org/10.1021/jf9800099

30. Van der Weijde T, Huxley LM, Hawkins S, et al (2017) Impact of drought stress on growth and quality of miscanthus for biofuel production. Glob Change Biol BioEnergy 9:770-782.

https://doi.org/10.1111/gcbb.12382

31. Torres AF, van der Weijde T, Dolstra O, et al (2013) Effect of Maize Biomass Composition on the Optimization of Dilute-Acid Pretreatments and Enzymatic Saccharification. BioEnergy Res 6:1038-1051. https://doi.org/10.1007/s12155-013-9337-0

32. Huyen TLN, Remond C, Dheilly RM, Chabbert B (2010) Effect of harvesting date on the composition and saccharification of Miscanthus x giganteus. Bioresour Technol 101:8224-8231. https://doi.org/10.1016/j.biortech.2010.05.087

33. Kaack K, Schwarz K, Brander P (2003) Variation in morphology, anatomy and chemistry of stems of Miscanthus genotypes differing in mechanical properties. Ind Crops Prod 17:131-142. https://doi.org/10.1016/\$0926-6690(02)00093-6

34. Meineke T, Manisseri C, Voigt CA (2014) Phylogeny in Defining Model Plants for Lignocellulosic Ethanol Production: A Comparative Study of Brachypodium distachyon, Wheat, Maize, and Miscanthus $x$ giganteus Leaf and Stem Biomass. PLOS ONE 9:. https://doi.org/10.1371/journal.pone.0103580

35. Jonkers K (2010) Models and orphans; concentration of the plant molecular life science research agenda. Scientometrics 83:167-179. https://doi.org/10.1007/s11192-009-0024-z 


\section{Illustrations}

Figure 1. Monthly mean temperature and precipitation in 2014 for the two sites (Le Moulon and Mons).

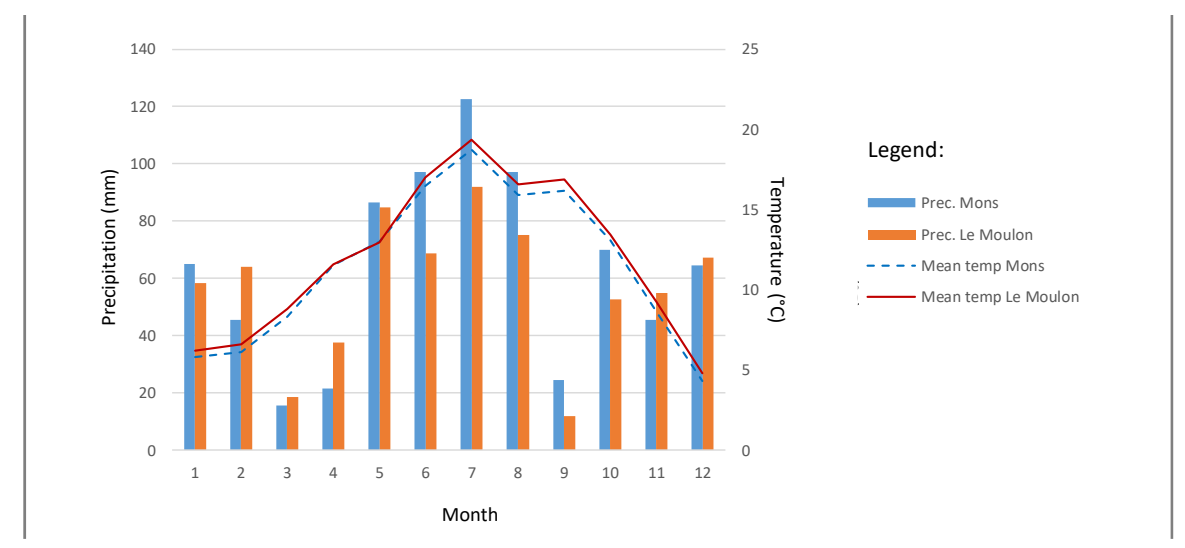

Figure 2. Fasga-stained cross-sections: maize on the left and miscanthus on the right.

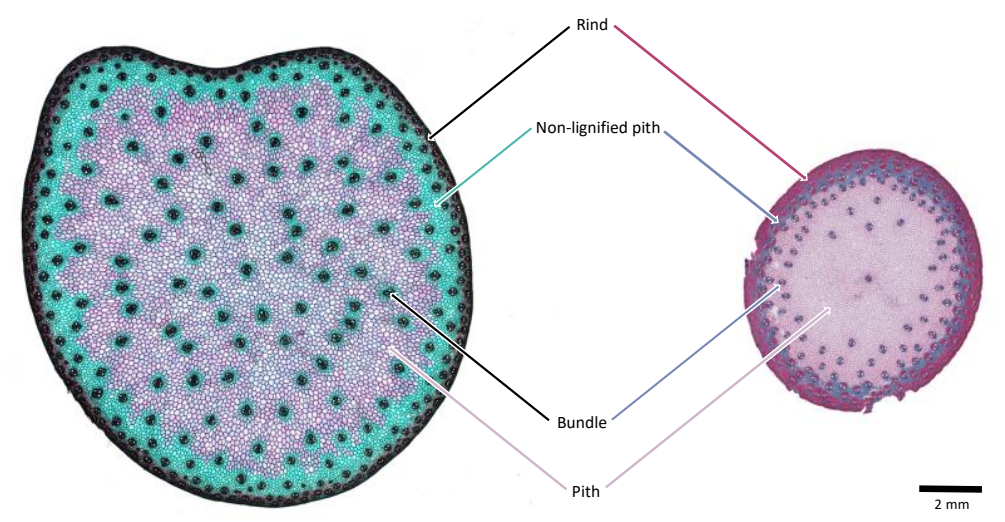

Figure 3. Correlation loading plot of the two first significant PLS components using the quantitative biochemical (text in green) and anatomical data (text in red). It displays the correlation between these variables and the components, and how the crop categories (black text) correlate with these variables.

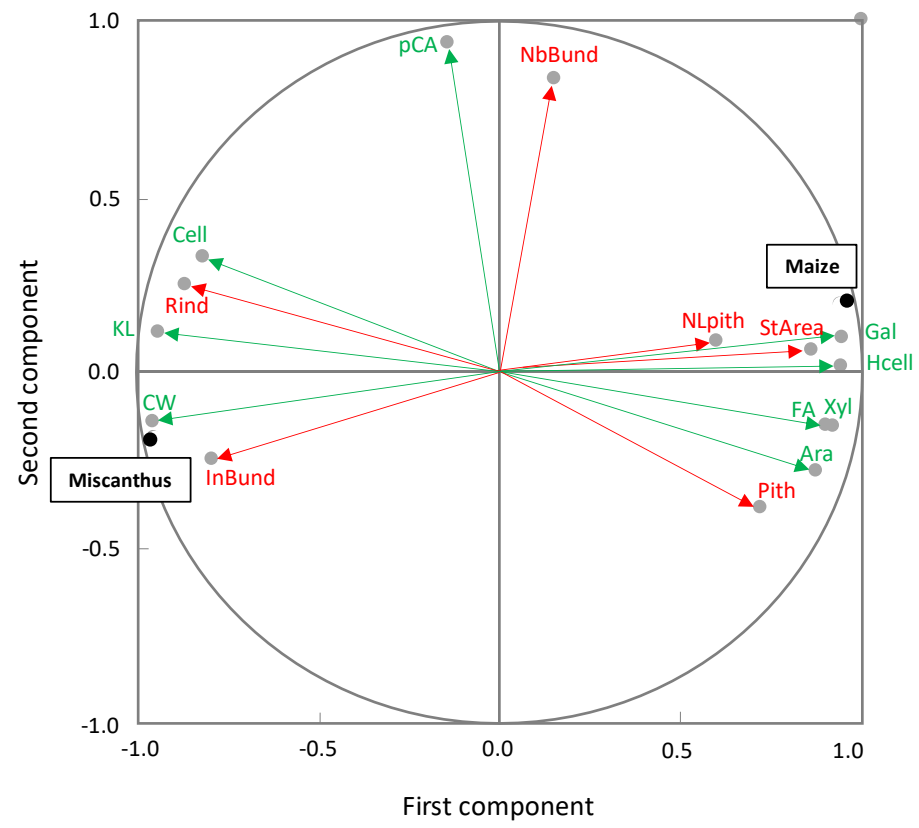


Figure 4. The PLS2 loading plot made it possible to visualize the correlation structure of the $Y$ anatomical variables (text in red) and $\mathrm{X}$ biochemical variables (text in green) in the two first components.

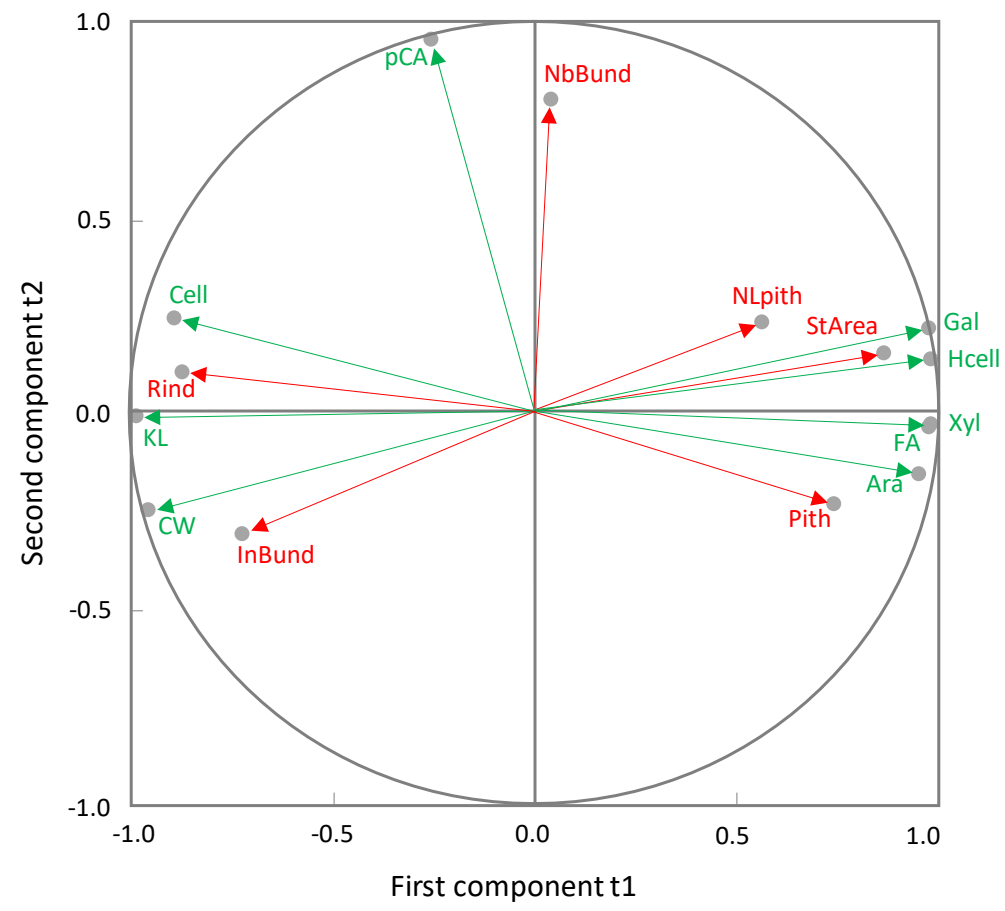

Figure 5 The plot of observations in the PLS2 two first components showed that the genotypes were scattered according to the crops (miscanthus in red text and maize in blue text) in the first component and that the second component showed a gradient among the maize genotypes and miscanthus in a lesser extent.

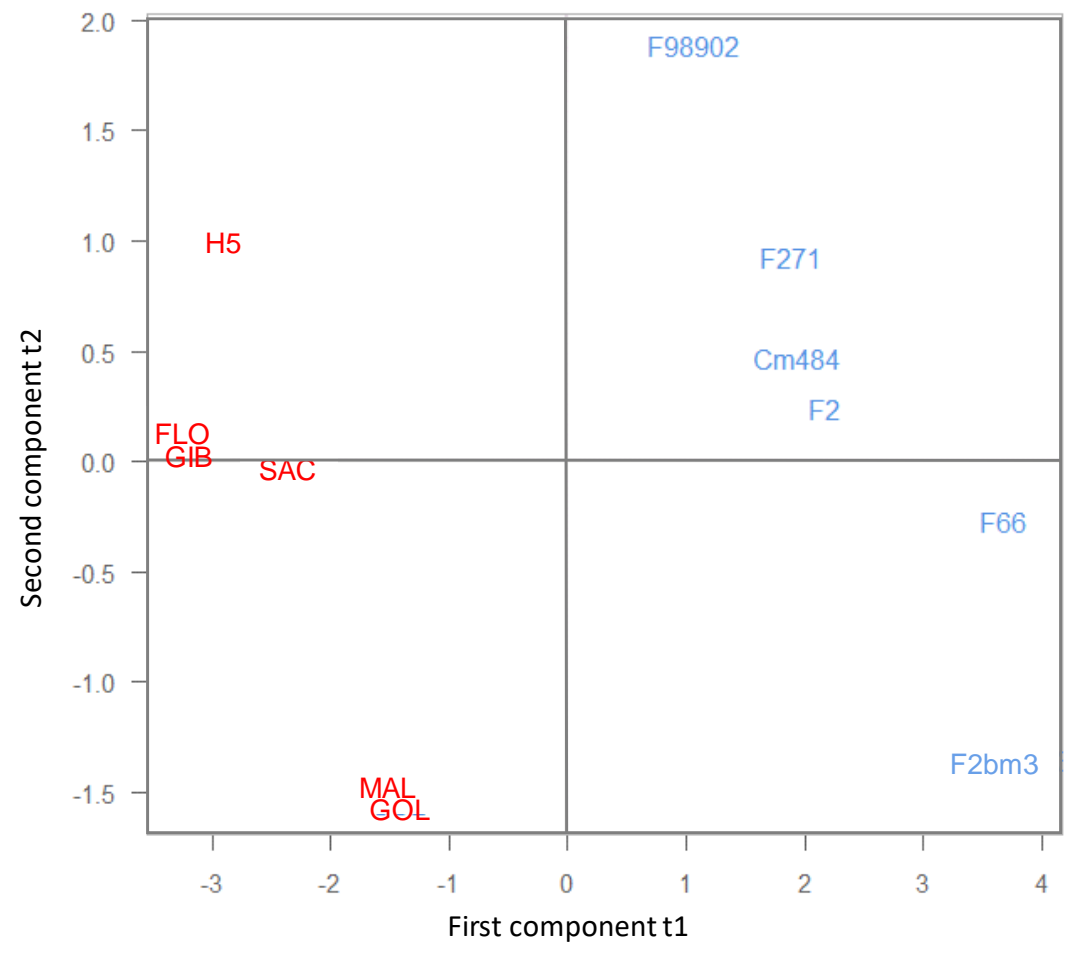


Figure 6. PLS1 loading plot displayed the correlation structure of the $Y$ digestibility variable (text in blue) and the $\mathrm{X}$ biochemical (text in green) and anatomical data (text in red) in the two first components: a) PLS1 grouping maize and miscanthus data together, b) using only maize and c) using miscanthus.

a) Maize and Miscanthus

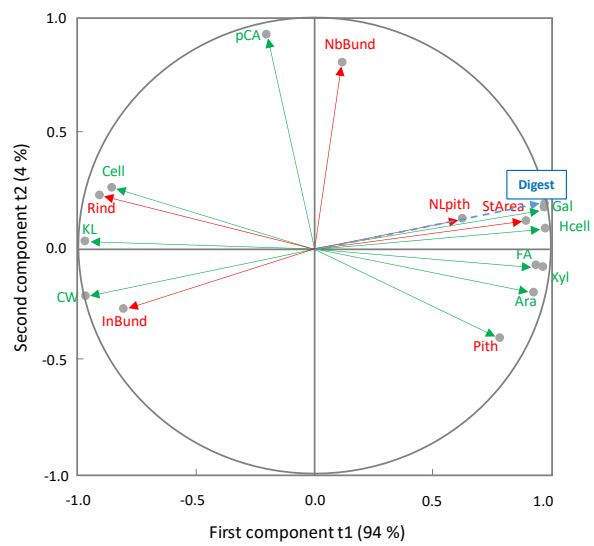

b) Maize

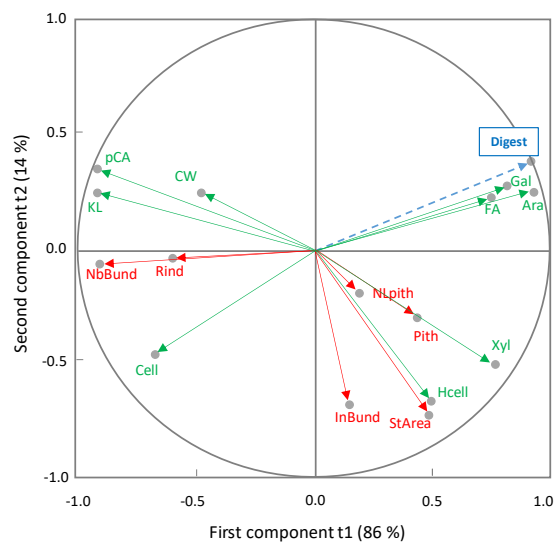

c) Miscanthus

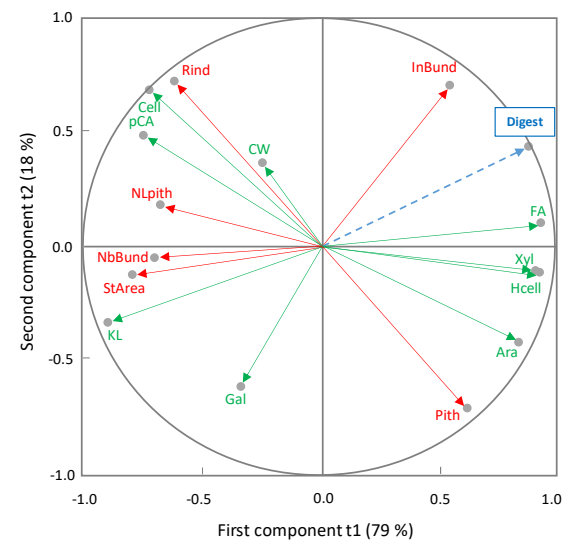

Figure 7. PLS1 loading plot displayed the correlation structure of the $Y$ tensile strength variable (text in blue) and the $X$ biochemical variables (text in green) and anatomical data (text in red) in the two first components: a) PLS1 grouping maize and miscanthus data together, b) using only maize and c) using miscanthus.

a) Maize and Miscanthus

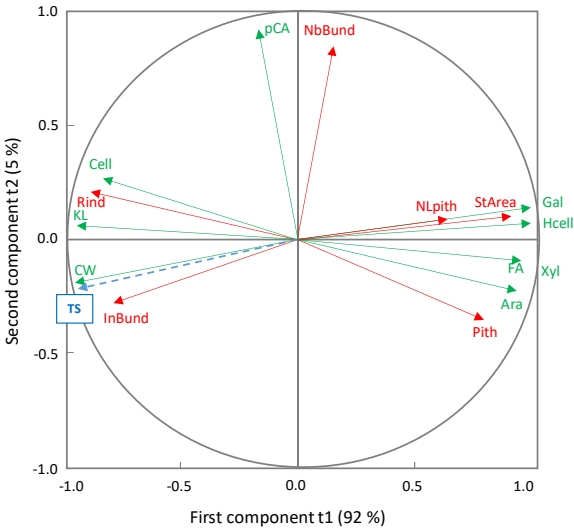

b) Maize

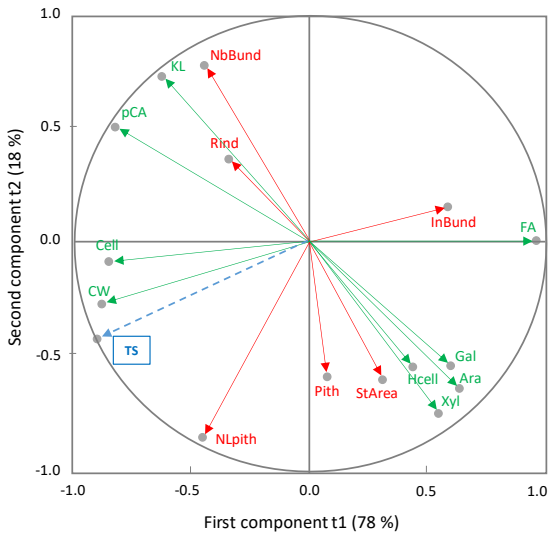

c) Miscanthus

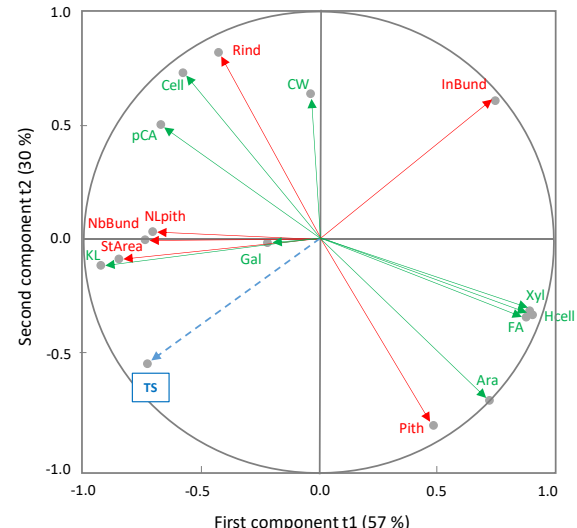


Table 1. Analysis of variance for biochemical variables. Student-Newman-Keuls test provided multiple comparison of means: means followed by the same letter are not significantly different. Significance given at 0.05 probability level.

\begin{tabular}{|c|c|c|c|c|c|c|c|c|c|c|c|c|c|c|c|c|c|c|c|}
\hline & \multirow[b]{2}{*}{ df } & \multicolumn{2}{|c|}{$\begin{array}{l}\text { CW }\left({ }^{*}\right) \\
(\% \mathrm{DM})\end{array}$} & \multicolumn{2}{|c|}{$\begin{array}{c}\text { Cell } \\
\text { (mg/g CW) }\end{array}$} & \multicolumn{2}{|c|}{$\begin{array}{c}\text { Hcell } \\
(\mathrm{mg} / \mathrm{g} \mathrm{CW})\end{array}$} & \multicolumn{2}{|c|}{$\begin{array}{c}\text { Xyl } \\
(\mathrm{mg} / \mathrm{g} \mathrm{CW})\end{array}$} & \multicolumn{2}{|c|}{$\begin{array}{c}\text { Ara } \\
(\mathrm{mg} / \mathrm{g} \mathrm{CW})\end{array}$} & \multicolumn{2}{|c|}{$\begin{array}{c}\text { Gal } \\
(\mathrm{mg} / \mathrm{g} \mathrm{CW})\end{array}$} & \multicolumn{2}{|c|}{$\begin{array}{c}\mathrm{KL} \\
(\mathrm{mg} / \mathrm{g} \mathrm{CW})\end{array}$} & \multicolumn{2}{|c|}{$\begin{array}{c}\mathrm{pCA} \\
(\mathrm{mg} / \mathrm{g} \mathrm{CW})\end{array}$} & \multicolumn{2}{|c|}{$\begin{array}{c}\text { FA } \\
(\mathrm{mg} / \mathrm{g} \mathrm{CW})\end{array}$} \\
\hline & & $\mathrm{F}$ & $\operatorname{Pr}(>F)$ & $\mathrm{F}$ & $\operatorname{Pr}(>F)$ & $\mathrm{F}$ & $\operatorname{Pr}(>\mathrm{F})$ & $\mathrm{F}$ & $\operatorname{Pr}(>\mathrm{F})$ & $\mathrm{F}$ & $\operatorname{Pr}(>\mathrm{F})$ & $\mathrm{F}$ & $\operatorname{Pr}(>\mathrm{F})$ & $\mathrm{F}$ & $\operatorname{Pr}(>\mathrm{F})$ & $\mathrm{F} \quad \mathrm{F}$ & $\operatorname{Pr}(>\mathrm{F})$ & $\mathrm{F}$ & $\operatorname{Pr}(>\mathrm{F})$ \\
\hline Species & 1 & - & - & 27.12 & $*$ & 887.29 & $*$ & 305.94 & * & 523.86 & * & 974.67 & $*$ & 950.94 & * & 0.26 & ns & 512.39 & $*$ \\
\hline Genotype & 10 & 13.52 & * & 2.10 & $*$ & 8.12 & $*$ & 7.76 & $*$ & 23.16 & $*$ & 3.28 & $*$ & 16.07 & * & 16.91 & $*$ & 13.54 & $*$ \\
\hline Species x Block & 3 & 0.65 & ns & 0.18 & ns & 1.09 & ns & 1.05 & ns & 0.79 & ns & 1.54 & ns & 0.09 & ns & 0.25 & ns & 0.54 & ns \\
\hline \multirow[t]{2}{*}{ Residuals } & 15 & & & & & & & & & & & & & & & & & & \\
\hline & Genoty & & & & & & & & & & & & & & & & & & \\
\hline \multicolumn{20}{|l|}{ M } \\
\hline i & FLO & 96.8 & & 453.6 & & $151.4 \mathrm{f}$ & & 129.5 & & 14.5 & & $2.37 \mathrm{c}$ & & 257.1 & & $21.9 \mathrm{~b}$ & & 3.16 & \\
\hline $\begin{array}{l}s \\
c\end{array}$ & SAC & 96.3 & & 454.1 & & 175.7 & & 150.8 & de & 15.3 & & $2.15 c$ & & 223.1 & & $21.4 \mathrm{~b}$ & & 4.26 & \\
\hline a & MAL & 95.4 & & 415.3 & $a b c$ & 191.4 & & 164.6 & & 18.9 & & $2.38 \mathrm{c}$ & & 232.2 & & $15.7 \mathrm{c}$ & & 4.09 & \\
\hline n & GIB & 94.4 & & 445.6 & & $149.6 \mathrm{f}$ & & 128.4 & & 14.0 & & $2.37 c$ & & 259.6 & & 21.7 & & 3.19 & \\
\hline $\begin{array}{l}\text { t } \\
h\end{array}$ & $\mathrm{H} 5$ & 94.4 & & 451.3 & & 168.0 & & 145.7 & & 15.0 & & $2.13 c$ & & 253.4 & & 26.0 & & 3.47 & \\
\hline \multirow{2}{*}{$\begin{array}{l}\mathrm{u} \\
\mathrm{s}\end{array}$} & $\mathrm{GOL}$ & 93.8 & & 418.5 & $a b c$ & 184.2 & & 156.8 & & 20.4 & & $2.16 \mathrm{c}$ & & 233.9 & & $15.7 \mathrm{c}$ & & 4.89 & \\
\hline & $\mathrm{Cm} 484$ & $64 \mathrm{~b}$ & & 428.0 & $a b c$ & 293.4 & & 214.4 & & 28.3 & & 8.35 & & 159.4 & & 20.7 & & 5.75 & \\
\hline M & F98902 & $63.5 \mathrm{~b}$ & & 401.9 & $a b c$ & 260.0 & & 177.4 & & 22.4 & & 8.10 & & 193.4 & & 28.3 & & 6.00 & \\
\hline a & F66 & $63 \mathrm{~b}$ & & 380.7 & & 315.4 & & 222.3 & & 40.0 & & 10.90 & & 148.4 & & 19.0 & & 6.35 & \\
\hline$z$ & F271 & $61 \mathrm{~b}$ & bc & 415.6 & $a b c$ & 324.3 & & 211.7 & & 22.9 & & 8.40 & & 174.6 & & 22.2 & & 5.65 & \\
\hline \multirow[t]{2}{*}{ e } & $\mathrm{F} 2$ & $59 \mathrm{~b}$ & $b c$ & 397.5 & $a b c$ & 276.1 & & 191.2 & & 30.3 & & 8.95 & & 177.9 & & 20.6 & & 6.30 & \\
\hline & $\mathrm{F} 2 \mathrm{bm} 3$ & $57 c$ & & 375.5 & & 311.0 & & 226.6 & & 34.5 & & 9.50 & & $143.0 \mathrm{f}$ & & $13.8 \mathrm{c}$ & & 7.35 & \\
\hline \multicolumn{2}{|l|}{ Maize mean } & 61.3 & & 399.8 & & 296.7 & & 207.2 & & 29.7 & & 9.0 & & 166.1 & & 20.7 & & 6.2 & \\
\hline \multicolumn{2}{|l|}{ Miscanthus mean } & 95.2 & & 439.7 & & 170.1 & & 146.0 & & 16.3 & & 2.3 & & 243.2 & & 20.4 & & 3.8 & $3 \mathrm{~b}$ \\
\hline \multicolumn{2}{|c|}{ Both species mean } & 78.2 & & 419.8 & & 233.4 & & 176.6 & & 23.0 & & 5.6 & & 204.7 & & 20.6 & & 5.0 & \\
\hline \multicolumn{2}{|c|}{ Coefficient of variation (\%) } & 1.4 & & 4.9 & & 4.9 & & 5.3 & & 6.8 & & 10.3 & & 3.3 & & 8.0 & & 5.6 & \\
\hline
\end{tabular}

$\left({ }^{*}\right)$ Blocks available only on maize: $\mathrm{df}=5$ for genotype effect and $\mathrm{df}=1$ for block effect.

Table 2. Analysis of variance for anatomical variables. Student-Newman-Keuls test provided multiple comparison of means: means followed by the same letter are not significantly different. Significance given at 0.05 probability level.

\begin{tabular}{|c|c|c|c|c|c|c|c|c|c|c|c|c|c|}
\hline & \multirow[b]{2}{*}{ df } & \multicolumn{2}{|c|}{$\begin{array}{l}\text { StArea } \\
\left(\mathrm{mm}^{2}\right)\end{array}$} & \multicolumn{2}{|c|}{$\begin{array}{l}\text { Rind } \\
(\%)\end{array}$} & \multicolumn{2}{|c|}{$\begin{array}{l}\text { Pith } \\
\text { (\%) }\end{array}$} & \multicolumn{2}{|c|}{$\begin{array}{c}\text { NLpith } \\
\text { (\% of pith) }\end{array}$} & \multicolumn{2}{|c|}{$\begin{array}{l}\text { NbBund } \\
\text { (in pith) }\end{array}$} & \multicolumn{2}{|c|}{$\begin{array}{c}\text { InBund } \\
\left(\mathrm{nb} / \mathrm{mm}^{2}\right)\end{array}$} \\
\hline & & $\mathrm{F}$ & $\operatorname{Pr}(>\mathrm{F})$ & $\mathrm{F}$ & $\operatorname{Pr}(>\mathrm{F})$ & $\mathrm{F}$ & $\operatorname{Pr}(>\mathrm{F})$ & $\mathrm{F}$ & $\operatorname{Pr}(>\mathrm{F})$ & $\mathrm{F}$ & $\operatorname{Pr}(>\mathrm{F})$ & $\mathrm{F}$ & $\operatorname{Pr}(>\mathrm{F})$ \\
\hline Species & 1 & 254.29 & $*$ & 139.59 & $*$ & 43.53 & $*$ & 15.16 & * & 14.29 & $*$ & 220.61 & $*$ \\
\hline Genotype & 10 & 7.44 & $*$ & 9.44 & $*$ & 8.40 & $*$ & 2.30 & ns & 12.08 & $*$ & 12.02 & $*$ \\
\hline Species x Block & 3 & 0.47 & ns & 0.79 & ns & 0.80 & ns & 0.63 & ns & 0.99 & ns & 0.41 & ns \\
\hline \multirow[t]{3}{*}{ Residuals } & 13 & & & & & & & & & & & & \\
\hline & \multicolumn{13}{|c|}{ Genotypes } \\
\hline & F271 & \multicolumn{2}{|l|}{507.8 a } & \multicolumn{2}{|c|}{$16.5 \mathrm{~b}$} & \multicolumn{2}{|c|}{$79.6 \mathrm{ab}$} & \multicolumn{2}{|l|}{17.4} & \multicolumn{2}{|c|}{$164.0 \mathrm{a}$} & \multicolumn{2}{|c|}{$0.3 \mathrm{~d}$} \\
\hline M & $\mathrm{F} 2$ & \multicolumn{2}{|l|}{468.6 a } & \multicolumn{2}{|c|}{$10.9 \mathrm{~b}$} & \multicolumn{2}{|c|}{$83.7 \mathrm{ab}$} & \multicolumn{2}{|l|}{18.7} & \multicolumn{2}{|c|}{$116.0 \mathrm{bc}$} & \multicolumn{2}{|c|}{$0.2 \mathrm{~d}$} \\
\hline a & $\mathrm{Cm} 484$ & \multicolumn{2}{|l|}{$452.5 \mathrm{a}$} & \multicolumn{2}{|c|}{$11.1 \mathrm{~b}$} & \multicolumn{2}{|c|}{86.2 a } & \multicolumn{2}{|l|}{41.9} & \multicolumn{2}{|c|}{$106.5 \mathrm{bc}$} & \multicolumn{2}{|c|}{$0.2 \mathrm{~d}$} \\
\hline $\begin{array}{l}i \\
z\end{array}$ & F66 & \multicolumn{2}{|l|}{429.2 a } & \multicolumn{2}{|c|}{$13.9 \mathrm{~b}$} & \multicolumn{2}{|c|}{$80.6 \mathrm{ab}$} & 28.1 & & 85.0 & $\mathrm{bc}$ & 0.2 & \\
\hline e & $\mathrm{F} 2 \mathrm{bm} 3$ & $418.2 a$ & & 11.2 & & 83.0 & & 14.7 & & 104.5 & $\mathrm{bc}$ & 0.3 & \\
\hline & F98902 & $108.9 \mathrm{~b}$ & & 15.4 & & 78.3 & & 13.3 & & 173.5 & & 0.2 & \\
\hline м & & & & & & & & & & & & & \\
\hline $\begin{array}{l}i \\
s\end{array}$ & FLO & $112.3 \mathrm{~b}$ & & 30.8 & & 69.2 & & 16.4 & & 128.3 & & 1.7 & \\
\hline c & $\mathrm{H} 5$ & $110.3 \mathrm{~b}$ & & 26.1 & & 73.9 & & 10.0 & & 169.3 & & 2.1 & $b c$ \\
\hline $\begin{array}{l}a \\
n\end{array}$ & GIB & $46.0 \mathrm{~b}$ & & 31.0 & & 69.0 & & 11.7 & & 97.7 & $\mathrm{bc}$ & 3.5 & \\
\hline $\begin{array}{l}n \\
t\end{array}$ & MAL & $31.2 \mathrm{~b}$ & & 16.7 & & 83.3 & & 4.2 & & 88.3 & $b c$ & 3.4 & \\
\hline $\mathrm{h}$ & $\mathrm{GOL}$ & $28.4 \mathrm{~b}$ & & 18.8 & & 81.2 & & 11.4 & & 70.2 & & 3.5 & \\
\hline $\begin{array}{l}\text { u } \\
\text { s }\end{array}$ & SAC & $16.2 \mathrm{~b}$ & & 33.6 & & 66.4 & & 9.4 & & 74.8 & & 7.0 & \\
\hline Maize mean & & $397.5 \mathrm{a}$ & & 13.1 & & 81.9 & & 22.3 & & 124.9 & & 0.2 & \\
\hline Miscanthus mean & & $57.4 \mathrm{~b}$ & & 26.2 & & 73.8 & & 10.5 & & 104.8 & & 3.5 & \\
\hline Both species mear & & 227.5 & & 19.6 & & 77.9 & & 16.4 & & 114.8 & & 1.9 & \\
\hline Coefficient of varia & ion (\%) & 24.6 & & 14.2 & & 0.4 & & 47.9 & & 13.5 & & 29.7 & \\
\hline
\end{tabular}


Table 3. Analysis of variance for digestibility of the stem and mechanical properties of stem-based polymer composites. Student-Newman-Keuls test provided multiple comparison of means: means followed by the same letter are not significantly different. Significance given at 0.05 probability level.

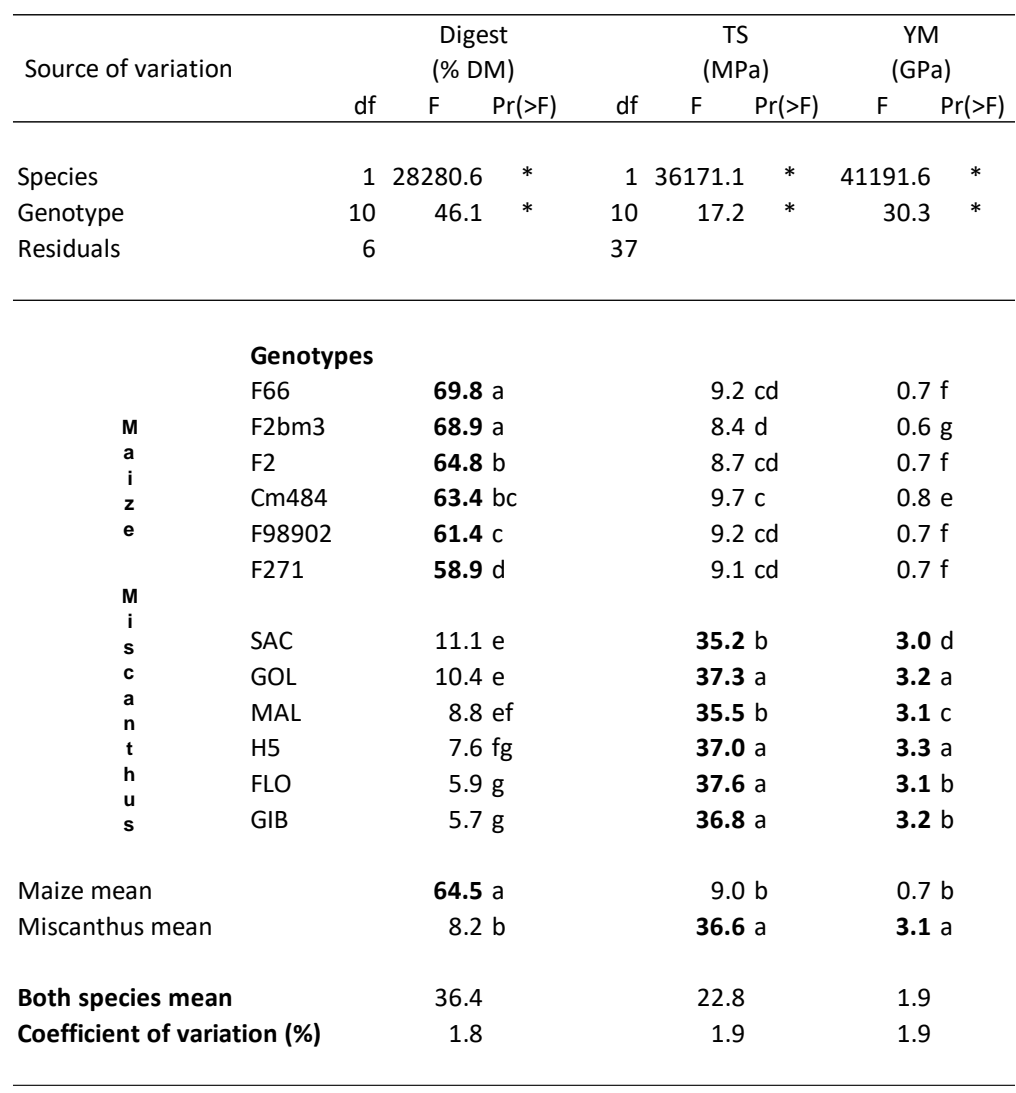

Table 4. Percentages of variances of $X$ biochemical variables (text in blue) and $Y$ anatomical variables (text in red) explained by the two components $\mathrm{t} 1$ and $\mathrm{t} 2$.

\begin{tabular}{lcccc}
\hline & $\mathbf{R}^{2} \mathbf{X}$ & $\begin{array}{c}\mathbf{R}^{2} \mathbf{X} \\
\text { cumulated }\end{array}$ & $\mathbf{R}^{2} \mathbf{Y}$ & $\begin{array}{c}\mathbf{R}^{2} \mathbf{Y} \\
\text { cumulated }\end{array}$ \\
\hline First component t1 & 0.82 & 0.82 & 0.47 & 0.47 \\
Second component t2 & 0.12 & 0.94 & 0.15 & 0.62 \\
\hline
\end{tabular}

\section{Supplemental tables available on request:}

Supplemental Table 1: Genotype means for all variables studied.

Supplemental Table 2: Biochemical and anatomical variables per genotype and per block.

Supplemental Table 3: Digestibility per genotype and per repetition.

Supplemental Table 4: Mechanical properties per genotype and per repetition.

Supplemental Table 5: Analysis of variance of aboveground biomass dry matter for both crops. StudentNewman-Keuls test provided multiple comparison of means: means followed by the same letter are not significantly different. Significance given at 0.05 probability level.

Supplemental Table 6: Analysis of variance for three biochemical variables measured for miscanthus during two consecutive years of testing and sampling (2014 and 2015). Significance given at 0.05 probability level. 